\title{
The effect of feeding regular or low $\alpha$-linolenic acid linseed on laying performance and total cholesterol content in eggs
}

\author{
R. Augustyn ${ }^{1,3}$, J. Barteczko ${ }^{1}$ and S. Smulikowska ${ }^{2}$ \\ ${ }^{1}$ Agricultural University of Cracow, Department of Animal Nutrition \\ Al. Mickiewicza 24/28, 30-059 Kraków, Poland \\ ${ }^{2}$ The Kielanowski Institute of Animal Physiology and Nutrition, \\ Polish Academy of Sciences \\ 05-110 Jabłonna, Poland
}

\begin{abstract}
The study was conducted on 90 Isa Brown hens aged 28 weeks, randomly allocated to 6 groups of 15 birds each and maintained in individual laying cages throughout 12 weeks of the experiment. Hens of control group were fed a standard diet containing $19 \mathrm{~g}$ crude fat per $\mathrm{kg}$, diets for the experimental groups contained $38 \mathrm{~g}$ crude fat per kg due to enrichment of the formula with $50 \mathrm{~g}$ of regular linseed cv. Opal or Omega (HA), low $\alpha$-linolenic linseed cv. Linola (LA), $20 \mathrm{~g}$ of LA linseed oil, or $20 \mathrm{~g}$ of soyabean oil. The increase in the dietary fat content in experimental groups decreased feed intake by $5 \%(\mathrm{P}<0.05)$, increased egg production by $4 \%(\mathrm{P}<0.05)$ except in the group with LA oil, and decreased egg weight by $2 \%$ on average $(\mathrm{P}<0.05)$, in comparison with the control group. The total cholesterol content averaged $284 \mathrm{mg}$ per egg in groups fed LA linseed or soyabean oil and in the control group, while in the groups fed LA linseed and LA oil, it averaged $291 \mathrm{mg}$ per egg $(\mathrm{P}<0.05)$. In conclusion, linseed cultivars with a high content of linoleic acid cannot be considered useful in production of functional eggs.
\end{abstract}

KEY WORDS: laying hens, linseed, oil seeds, egg yolks, cholesterol, triglycerides

\section{INTRODUCTION}

The egg is considered an ideal target for dietary modification leading to the development of functional food (Szymczyk and Pisulewski, 2003). Enrichment of laying hen diets with regular full-fat linseeds beneficially affected the functional value of eggs due to an increased content of $n-3$ polyunsaturated fatty acids (PUFA)

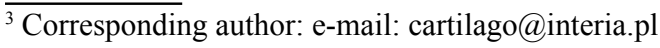


(Scheideler and Froning, 1996; Van Elswyk, 1997). Data concerning the influence of regular, high- $\alpha$-linolenic acid linseed on laying performance are conflicting, however, some authors have reported a decline in feed intake, body weight of layers, or egg yolk weight. The decline might be connected with linseed lignans, mucilages or fatty acid profile (Van Elswyk, 1997). In recent years linseed cultivars containing oil low in $\alpha$-linolenic acid and rich in linoleic acid have been introduced (Borowiec et al., 2001). Enrichment of laying hen diets with conjugated linoleic acid has been reported to decrease the yolk weight and cholesterol content of eggs (Szymczyk and Pisulewski, 2003). The aim of this study was to compare the effects of feeding laying hens with seeds of regular or modified low- $\alpha$-linolenic acid cultivars of linseed on laying performance and cholesterol content in eggs.

\section{MATERIAL AND METHODS}

The seeds of 3 linseed cultivars, regular high- $\alpha$-linolenic acid (HA) Omega and Opal, and modified, low- $\alpha$-linolenic acid (LA) Linola, were used in the study. LA linseed oil and soyabean oil were used as references. The linseeds were ground and incorporated into laying hen diets at the level of $50 \mathrm{~g} / \mathrm{kg}$, vegetable oils were incorporated at the level of $20 \mathrm{~g} / \mathrm{kg}$ to provide a similar amount of dietary fat; the control diet was not supplemented with fat (Table 1).

Table 1. Composition and nutritional value of diets, $\mathrm{g} / \mathrm{kg}$

\begin{tabular}{|c|c|c|c|c|c|c|}
\hline \multirow{3}{*}{ Item } & \multicolumn{6}{|c|}{ Dietary treatment } \\
\hline & \multirow[b]{2}{*}{ control } & \multicolumn{3}{|c|}{ linseed } & \multicolumn{2}{|c|}{ oil } \\
\hline & & $\begin{array}{c}\mathrm{HA}^{1} \\
\text { Omega }\end{array}$ & $\begin{array}{l}\mathrm{HA}^{1} \\
\text { Opal }\end{array}$ & $\begin{array}{c}\mathrm{LA}^{2} \\
\text { Linola }\end{array}$ & $\begin{array}{c}\mathrm{LA}^{2} \\
\text { linseed }\end{array}$ & soya \\
\hline \multicolumn{7}{|l|}{ Component } \\
\hline wheat & 577 & 552 & 552 & 547 & 552 & 552 \\
\hline maize & 100 & 100 & 100 & 100 & 100 & 100 \\
\hline soyabean meal & 160 & 135 & 135 & 140 & 165 & 165 \\
\hline meat-and-bone meal & 40 & 40 & 40 & 40 & 40 & 40 \\
\hline dehydrated lucerne & 20 & 20 & 20 & 20 & 20 & 20 \\
\hline linseeds & - & 50 & 50 & 50 & - & - \\
\hline vegetable oil & - & - & - & - & 20 & 20 \\
\hline limestone & 70 & 70 & 70 & 70 & 70 & 70 \\
\hline dicalcium phosphate & 25 & 25 & 25 & 25 & 25 & 25 \\
\hline sodium chloride & 3 & 3 & 3 & 3 & 3 & 3 \\
\hline mineral-vitamin premix & 5 & 5 & 5 & 5 & 5 & 5 \\
\hline \multicolumn{7}{|l|}{ Calculated } \\
\hline crude protein & 167 & 169 & 168 & 170 & 168 & 169 \\
\hline crude fat & 18.8 & 38.0 & 39.2 & 37.0 & 37.4 & 39.8 \\
\hline $\mathrm{ME}, \mathrm{MJ} / \mathrm{kg}$ & 11.00 & 11.40 & 11.38 & 11.43 & 11.46 & 11.50 \\
\hline
\end{tabular}

${ }^{1} \mathrm{HA}$ - linseed high in $\alpha$-linolenic acid; ${ }^{2} \mathrm{LA}$ - linseed and oil low in $\alpha$-linolenic acid and high in linoleic acid 
Ninety Isa Brown laying hens aged 28 weeks were divided into 6 groups of 15 birds and kept in individual cages in a battery system. Feed and water were provided ad libitum during the 12-week feeding trial. Feed intake was measured in weekly intervals, eggs were collected and weighed daily. Every week 5 eggs from each group were randomly selected, weighed, yolk, albumen and eggshell were separated and weighed. The colour of yolks was evaluated by a Roche 15 point yolk colour fan, then yolks were pooled within a group, homogenized and frozen at $-20^{\circ} \mathrm{C}$ until analysis. Total cholesterol and triglycerides were determined in egg yolks according to AOAC (1990). The results were subjected to one-way ANOVA GLM analysis (SAS Institute, 1996).

\section{RESULTS AND DISCUSSION}

The control diet contained $19 \mathrm{~g}$ crude fat $/ \mathrm{kg}$, while in experimental diets the crude fat level was doubled due to the added full-fat seeds or vegetable oils (Table 1). The dietary fatty acid profile (not presented) differed, as linseeds of the regular HA cultivars Omega and Opal had a high content of $\alpha$-linolenic acid, while linoleic acid predominated in the fatty acids of LA linseeds cv. Linola and LA oil, as well as in soya oil, which is in agreement with Borowiec et al. (2001).

Table 2. Performance of hens (28-40 weeks of life) and egg composition

\begin{tabular}{|c|c|c|c|c|c|c|c|}
\hline \multirow{3}{*}{ Item } & \multicolumn{7}{|c|}{ Dietary treatment } \\
\hline & \multirow[b]{2}{*}{ control } & \multicolumn{3}{|c|}{ linseed } & \multicolumn{2}{|c|}{ oil } & \multirow[b]{2}{*}{ SEM } \\
\hline & & $\begin{array}{c}\mathrm{HA}^{1} \\
\text { Omega }\end{array}$ & $\begin{array}{l}\text { HA }^{1} \\
\text { Opal }\end{array}$ & $\begin{array}{c}\mathrm{LA}^{2} \\
\text { Linola }\end{array}$ & $\begin{array}{c}\mathrm{LA}^{2} \\
\text { linseed }\end{array}$ & soya & \\
\hline Feed intake, g/day & $148.8^{\mathrm{b}}$ & $147.5^{\mathrm{b}}$ & $143.9^{b}$ & $144.6^{\mathrm{b}}$ & $131.4^{\mathrm{a}}$ & $140.0^{\mathrm{b}}$ & 2.10 \\
\hline Laying rate, $\%$ & $91.4^{\mathrm{a}}$ & $95.6^{\mathrm{b}}$ & $94.0^{\mathrm{b}}$ & $95.7^{\mathrm{b}}$ & $90.8^{\mathrm{a}}$ & $94.8^{\mathrm{b}}$ & 1.42 \\
\hline Egg weight, g & $61.2^{\mathrm{b}}$ & $60.6^{\mathrm{a}}$ & $59.9^{\mathrm{a}}$ & $59.4^{\mathrm{a}}$ & $58.7^{\mathrm{a}}$ & $60.8^{\mathrm{a}}$ & 0.91 \\
\hline $\mathrm{Kg}$ feed/kg eggs & $2.66^{\mathrm{b}}$ & $2.54^{\mathrm{a}}$ & $2.55^{\mathrm{a}}$ & $2.54^{\mathrm{a}}$ & $2.46^{\mathrm{a}}$ & $2.43^{\mathrm{a}}$ & 0.11 \\
\hline Yolk, g/egg & 15.3 & 15.5 & 15.2 & 15.1 & 15.3 & 15.3 & 0.59 \\
\hline Albumen, g/egg & $38.8^{\mathrm{ab}}$ & $37.6^{\mathrm{a}}$ & $37.5^{\mathrm{a}}$ & $36.8^{\mathrm{a}}$ & $36.8^{\mathrm{a}}$ & $39.1^{\mathrm{b}}$ & 1.88 \\
\hline Yolk colour $^{3}$ & $5.88^{\mathrm{a}}$ & $6.58^{\mathrm{b}}$ & $6.40^{\mathrm{b}}$ & $6.67^{\mathrm{b}}$ & $5.83^{\mathrm{a}}$ & $5.96^{\mathrm{a}}$ & 0.32 \\
\hline Triglycerides, g/egg & $5.73^{b}$ & $6.25^{\mathrm{c}}$ & $5.69^{\mathrm{b}}$ & $5.56^{\mathrm{ab}}$ & $5.73^{b}$ & $5.41^{\mathrm{a}}$ & 0.14 \\
\hline Cholesterol, mg/egg & $283^{\mathrm{a}}$ & $279^{\mathrm{a}}$ & $283^{\mathrm{a}}$ & $290^{\mathrm{ab}}$ & $293^{\mathrm{b}}$ & $285^{\mathrm{ab}}$ & 0.06 \\
\hline
\end{tabular}

${ }^{1}$ HA - linseed high in $\alpha$-linolenic acid; ${ }^{2}$ LA - linseed and oil low in $\alpha$-linolenic acid; ${ }^{3}$ according to Roche 15 points yolk colour fan ; ${ }^{a, b}$ means in rows with different letters differ significantly at $\mathrm{P}<0.05$

Introducing LA linseed oil into the dietary formula decreased feed intake by $14 \%$, soya oil decreased feed intake by $6 \%(\mathrm{P}<0.05)$. The laying rate in the group fed the diet with linseed oil was comparable with the control, while in the remaining groups, it was 3.6 percentage points higher. The eggs from hens fed experimental diets with linseeds or vegetable oils were generally smaller than from control birds $(\mathrm{P}<0.05)$, similarly as reported by Scheideler and Froning 
(1996). Eggs from birds provided with LA oil in their diet were 4\% smaller than control eggs. The proportions of yolk in egg were uniform among groups, while eggs from hens fed with linseeds or LA oil had less albumen than control eggs. Dietary linseeds increased the colour of egg yolks (Table 2).

The regular linseed had no effect on egg cholesterol, which is in agreement with Caston and Leeson (1990) and Scheideler and Froning (1996). However, feeding LA linseed or LA oil rich in linoleic acid increased the total cholesterol content of eggs.

\section{CONCLUSIONS}

Linseed cultivars with a high content of linoleic acid cannot be considered useful for production of functional eggs.

\section{REFERENCES}

AOAC, 2000. Official Methods of Analysis, Association of Official Analytical Chemists. $17^{\text {th }}$ Edition. Washington, DC

Caston L., Leeson S., 1990. Dietary flax and egg composition. Poultry Sci. 69, 1617-1620

Borowiec F., Zając T., Kowalski Z.M., Micek P., Marciński M., 2001. Comparison of nutritive value of new commercial linseed oily cultivars for ruminants. J. Anim. Feed Sci. 10, 301-308

Scheideler S.E., Froning G.W., 1996. The combined influence of dietary flaxseed variety, level, form, and storage conditions on egg production and composition among vitamin E supplemented hens. Poultry Sci. 75, 1221-1226

SAS, 1996. User's Guide: Statistics. Release 6.12. SAS Institute Inc. Cary, NC

Szymczyk B., Pisulewski P.M., 2003. Effects of dietary conjugated linoleic acid on fatty acid composition and cholesterol content of hen egg yolks. Brit. J. Nutr. 90, 93-99

Van Elswyk M.E., 1997. Nutritional and physiological effects of flax seed in diets for laying fowl. World Poultry Sci. J. 53, 253-264 